\title{
Burkholderia fungorum sp. nov. and Burkholderia caledonica sp. nov., two new species isolated from the environment, animals and human clinical samples
}

1 Laboratorium voor
Microbiologie, Universiteit
Gent, K. L.
Ledeganckstraat 35,
B-9000 Ghent, Belgium
2 Culture Collection,
Department of Clinical
Bacteriology, University of
Göteborg, Göteborg,
Sweden
3 Department of Medical
Microbiology, University of
Edinburgh, Edinburgh, UK

\section{INTRODUCTION}

The genus Burkholderia currently comprises 19 named species: Burkholderia andropogonis, Burkholderia caribensis, Burkholderia caryophylli, Burkholderia cepacia (comprising genomovars I, III and VI), Burkholderia gladioli, Burkholderia glathei, Burkholderia glumae, Burkholderia graminis, Burkholderia kururiensis, Burkholderia mallei, Burkholderia multivorans, Burkholderia phenazinium, Burkholderia plantarii, Burkholderia pseudomallei, Burkholderia pyrrocinia, Burkholderia stabilis (formerly B. cepacia genomovar IV), Burkholderia thailandensis, Burkholderia ubonensis and Burkholderia vietnamiensis (Yabuuchi et al., 1992,

The GenBank/EMBL/DDBJ accession numbers for the $16 \mathrm{~S}$ rDNA sequences of strains LMG $16225^{\top}$ (= CCUG 31961'), LMG 16307 and LMG 19076 ${ }^{\top}$ (= CCUG 42236') described in this work are respectively AF215705, AF215706 and AF215704.
1995, 2000; Gillis et al., 1995; Vandamme et al., 1997, 2000; Viallard et al., 1998; Brett et al., 1998; Achouak et al., 1999; Coenye et al., 1999a, 2001; Zhang et al., 2000). Within this genus, there are several stable phylogenetic clusters, one of which contains $B$. graminis (an organism isolated from agricultural soils in France and Australia), B. caribensis (an exopolysaccharide-producing organism isolated from the soil in Martinique), B. phenazinium, B. glathei (both isolated from soil) and several unidentified xenobioticcompound-degrading strains (Viallard et al., 1998; Achouak et al., 1999).

In an ongoing survey of $B$. cepacia-like organisms (using whole-cell protein analysis), 16 isolates from human, animal and environmental specimens exhibited striking similarity to $B$. graminis and $B$. caribensis strains. This prompted the polyphasic taxonomic study described below. 


\section{METHODS}

Bacterial strains and growth conditions. Reference strains of B. graminis, B. caribensis, B. phenazinium and B. glathei and the 16 novel $B$. cepacia-like isolates are listed in Table 1. Reference strains of $B$. andropogonis, $B$. caryophylli, $B$. cepacia genomovars I, III and VI, B. gladioli, B. glumae, $B$. multivorans, $B$. plantarii, $B$. pseudomallei, $B$. pyrrocinia, $B$. stabilis and $B$. vietnamiensis have been described previously (Vandamme et al., 1997, 2000; Coenye et al., 2001). The seven strains here assigned to Burkholderia caledonica sp. nov. were isolated from rhizosphere soil, as described previously (Butler et al., 1995). Strains were grown aerobic- ally on Trypticase Soy Agar (BBL) and incubated at $37^{\circ} \mathrm{C}$ unless otherwise indicated.

SDS-PAGE of whole-cell proteins. Strains were grown on nutrient agar (CM3; Oxoid) supplemented with $0.04 \%$ $(\mathrm{w} / \mathrm{v}) \mathrm{KH}_{2} \mathrm{PO}_{4}$ and $0 \cdot 24 \%(\mathrm{w} / \mathrm{v}) \mathrm{Na}_{2} \mathrm{HPO}_{4} .12 \mathrm{H}_{2} \mathrm{O}(\mathrm{pH} 6 \cdot 8)$ and incubated for $48 \mathrm{~h}$ at $28{ }^{\circ} \mathrm{C}$. Preparation of whole-cell proteins and SDS-PAGE were performed as described previously (Pot et al., 1994). Densitometric analysis, normalization and interpolation of the protein profiles and numerical analysis using Pearson's product-moment correlation coefficient were performed using the GELCOMPAR 4.2 software package (Applied Maths).

Table 1. List of Burkholderia strains studied

Abbreviations: ATCC, American Type Culture Collection, Manassas, VA, USA; CCUG, Culture Collection, University of Göteborg, Department of Clinical Bacteriology, Göteborg, Sweden; LMG, BCCM/LMG Bacteria Collection, Laboratorium voor Microbiologie, Universiteit Gent, Gent, Belgium; NCIB, National Collection of Industrial Bacteria, Aberdeen, UK.

\begin{tabular}{|c|c|c|c|c|}
\hline $\begin{array}{l}\text { Original strain } \\
\text { designation }\end{array}$ & $\begin{array}{l}\text { BCCM/LMG } \\
\text { strain no. }\end{array}$ & $\begin{array}{l}\text { Other strain } \\
\text { designation }\end{array}$ & Origin & Source \\
\hline \multicolumn{5}{|l|}{ B. caribensis } \\
\hline MWAP64 $^{\mathrm{T}}$ & LMG $18531^{\mathrm{T}}$ & CCUG $42847^{\mathrm{T}}$ & T. Heulin & Vertisol (Martinique) \\
\hline MWAP84 & LMG 18532 & CCUG 42848 & T. Heulin & Vertisol (Martinique) \\
\hline \multicolumn{5}{|l|}{ B. glathei } \\
\hline ATCC $29195^{\mathrm{T}}$ & LMG $14190^{\mathrm{T}}$ & - & ATCC & Lateritic soil (Germany) \\
\hline ATCC 29198 & LMG 14932 & - & ATCC & Lateritic soil (Germany) \\
\hline \multicolumn{5}{|l|}{ B. graminis } \\
\hline ATCC $700544^{\mathrm{T}}$ & LMG $18924^{\mathrm{T}}$ & CCUG $42231^{\mathrm{T}}$ & ATCC & Maize senescent root system (France) \\
\hline C3A1M & LMG 18947 & CCUG 42844 & J. Balandreau & Maize senescent root system (France) \\
\hline C5A1M & LMG 18948 & CCUG 42845 & J. Balandreau & Maize senescent root system (France) \\
\hline AUS33 & LMG 18949 & CCUG 42843 & J. Balandreau & $\begin{array}{l}\text { Wheat pasture rotation (Kapunda, } \\
\text { Australia) }\end{array}$ \\
\hline \multicolumn{5}{|l|}{ B. phenazinium } \\
\hline NCIB $11027^{\mathrm{T}}$ & LMG $2247^{\mathrm{T}}$ & CCUG $20836^{\mathrm{T}}$ & NCIB & Soil enriched with threonine \\
\hline NCIB 11431 & LMG 6868 & CCUG 42269 & NCIB & \\
\hline \multicolumn{5}{|c|}{ B. fungorum sp. nov. } \\
\hline Croize P763-2 $2^{\mathrm{T}}$ & LMG $16225^{\mathrm{T}}$ & CCUG $31961^{\mathrm{T}}$ & F. Seigle-Murandi & Phanerochaete chrysosporium \\
\hline BIOLOG 1786 & LMG 18809 & CCUG 22618 & B. Bochner & \\
\hline LMG 18810 & LMG 18810 & CCUG 30784 & K. Eriksson & Haemoglobin solution (Sweden, 1992) \\
\hline Croize PK32 & $\mathrm{R}-3471$ & CCUG 31959 & F. Seigle-Murandi & Phanerochaete chrysosporium \\
\hline V02 10158 & R-8655 & CCUG 42846 & R. Zbinden & Vaginal secretion of pregnant woman \\
\hline SVA B1549/99 & R-9502 & CCUG 42397 & E. Eriksson & Mouse nose (1999) \\
\hline SVA B1555/99 & R-9503 & CCUG 42398 & E. Eriksson & Mouse nose (1999) \\
\hline GDXE P1196(1) & LMG 16226 & CCUG 32541 & F. Seigle-Murandi & Phanerochaete chrysosporium \\
\hline LMG 16307 & LMG 16307 & CCUG 18424 & $\begin{array}{l}\text { PHLS Sundsvall, } \\
\text { Sweden }\end{array}$ & $\begin{array}{l}\text { Cerebrospinal fluid of 66-year-old woman } \\
\text { (Sweden, 1986) }\end{array}$ \\
\hline \multicolumn{5}{|c|}{ B. caledonica sp. nov. } \\
\hline W50D ${ }^{T}$ & LMG $19076^{\mathrm{T}}$ & CCUG $42236^{\mathrm{T}}$ & Our isolate & Rhizosphere soil (Edinburgh, UK) \\
\hline W51E & LMG 19077 & CCUG 42237 & Our isolate & Rhizosphere soil (Edinburgh, UK) \\
\hline W53B & LMG 19078 & CCUG 42238 & Our isolate & $\begin{array}{l}\text { Rhizosphere soil of vine plant } \\
\text { (Edinburgh, UK) }\end{array}$ \\
\hline W73C & $\mathrm{R}-4186$ & CCUG 42239 & Our isolate & $\begin{array}{l}\text { Sandy rhizosphere soil } \\
\text { (Abernethy Forest, UK) }\end{array}$ \\
\hline W47F & R-4187 & CCUG 42233 & Our isolate & Rhizosphere soil (Edinburgh, UK) \\
\hline W50C & R-4188 & CCUG 42235 & Our isolate & Rhizosphere soil (Edinburgh, UK) \\
\hline W49D & R-4192 & CCUG 42234 & Our isolate & Rhizosphere soil (Edinburgh, UK) \\
\hline
\end{tabular}




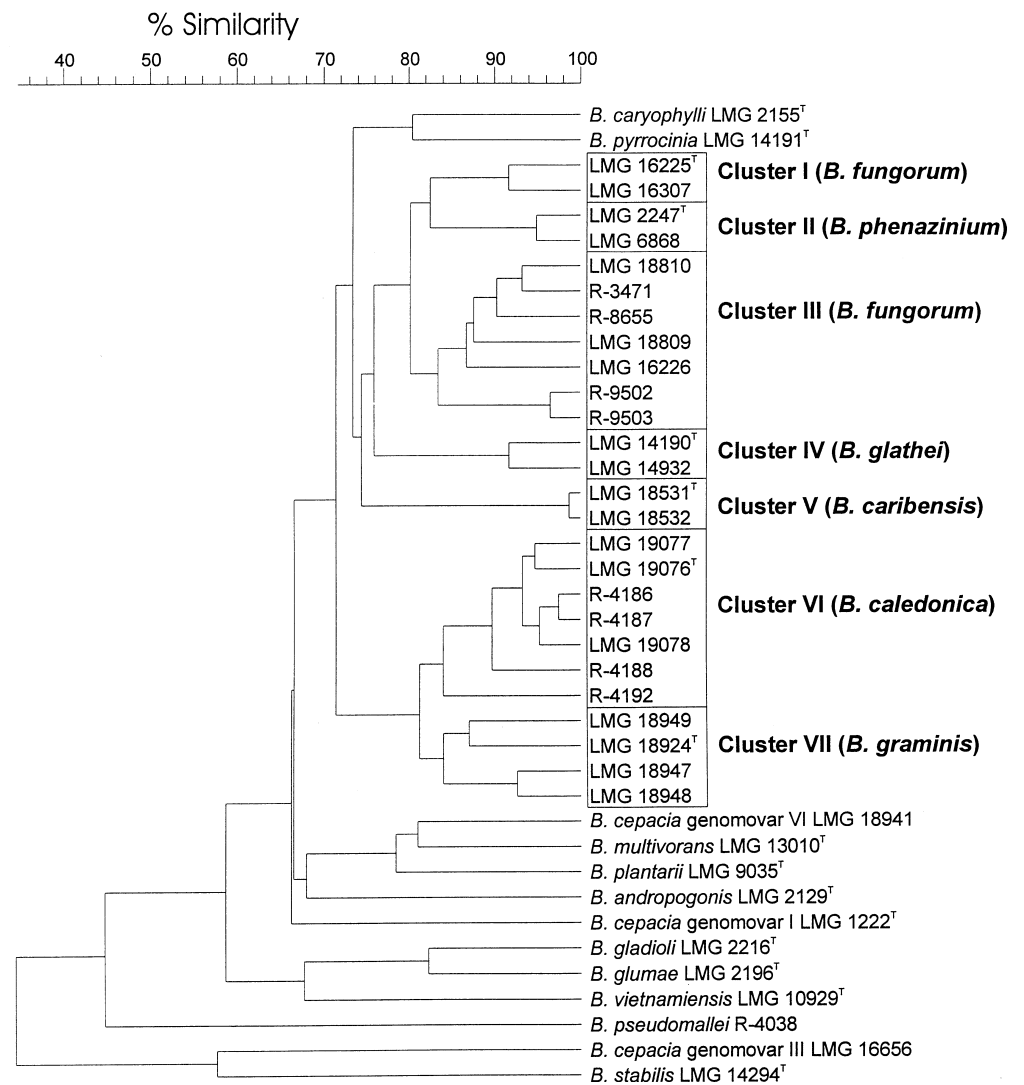

Fig. 1. Dendrogram derived from the unweighted pair group mean linkage of correlation coefficients between the protein patterns of the strains studied. For convenience, the correlation coefficients are expressed as percentages of similarity.
DNA preparation. DNA was prepared as described previously by Pitcher et al. (1989).

$16 S$ rDNA sequencing. The nearly complete sequences (corresponding to positions 8-1541 in the Escherichia coli numbering system) of the 16S rRNA genes of strains LMG $16225^{\mathrm{T}}\left(=\right.$ CCUG 31961 $\left.{ }^{\mathrm{T}}\right)$, LMG 16307 and LMG $19076^{\mathrm{T}}($ $=$ CCUG 42236 $6^{\mathrm{T}}$ ) were amplified by the PCR using conserved primers 5'-AGAGTTTGATCCTGGCTGAG-3' (positions 8-27) and 5'-AAGGAGGTGATCCAGCCGCA-3' (positions 1521-1541) (Coenye et al., 1999b). The PCR products were purified using a QIAquick PCR purification kit (Qiagen) according to the manufacturer's instructions. Sequence analysis was performed using an Applied Biosystems 310 DNA sequencer and the protocols of the manufacturer (Perkin-Elmer), with the ABI Prism Dye Terminator Cycle Sequencing Ready Reaction kit. The sequencing primers were those given by Coenye et al. (1999b). Sequence assembly was performed by using the program AUTOASSEMBLER (Perkin-Elmer). Phylogenetic analysis was performed using the GENECOMPAR 2.1 software package (Applied Maths). A phylogenetic tree based on the neighbour-joining method was constructed.

Determination of the DNA base composition. DNA was degraded enzymically into nucleosides, as described by Mesbah et al. (1989). The nucleoside mixture obtained was then separated by HPLC, using a Waters SymmetryShield $\mathrm{C} 8$ column with a thermostat set at $37^{\circ} \mathrm{C}$. The solvent was $0.02 \mathrm{M} \mathrm{NH}_{4} \mathrm{H}_{2} \mathrm{PO}_{4}(\mathrm{pH} 4.0)$ with $1.5 \%$ acetonitrile. Nonmethylated $\lambda$ phage DNA (Sigma) was used as the calibration reference.

DNA-DNA hybridizations. DNA-DNA hybridizations were performed with photobiotin-labelled probes in microplate wells, as described by Ezaki et al. (1989), using an HTS7000 Bio Assay Reader (Perkin-Elmer) for the fluorescence measurements. The hybridization temperature was $50{ }^{\circ} \mathrm{C}$ in $50 \%$ formamide. Each value given is the mean of at least two hybridization experiments.

Fatty acid methyl ester analysis. After an incubation period of $24 \mathrm{~h}$ at $28^{\circ} \mathrm{C}$, a loopful of well-grown cells was harvested and fatty acid methyl esters were prepared, separated and identified by using the Microbial Identification System (Microbial ID) described elsewhere (Vandamme et al., 1992).

Phenotypic characterization. Classical phenotypic tests were performed as described previously (Vandamme et al., 1993). API ZYM and API20 NE tests were performed according to the recommendations of the manufacturer (bioMérieux).

\section{RESULTS}

\section{SDS-PAGE of whole-cell proteins}

Whole-cell protein extracts were prepared from all 16 novel isolates and from reference strains of known Burkholderia species. The reproducibility was checked by preparing protein extracts in duplicate. The correlation level between the patterns obtained with different extracts of the same strain was more than $93 \%$ (data not shown). After numerical analysis and visual comparison of the profiles, seven clusters could be delineated (Fig. 1). B. phenazinium, B. glathei, B. caribensis and $B$. graminis reference strains each formed distinct clusters (clusters II, IV, V and VII, respectively). Reference strains from other Burk- 

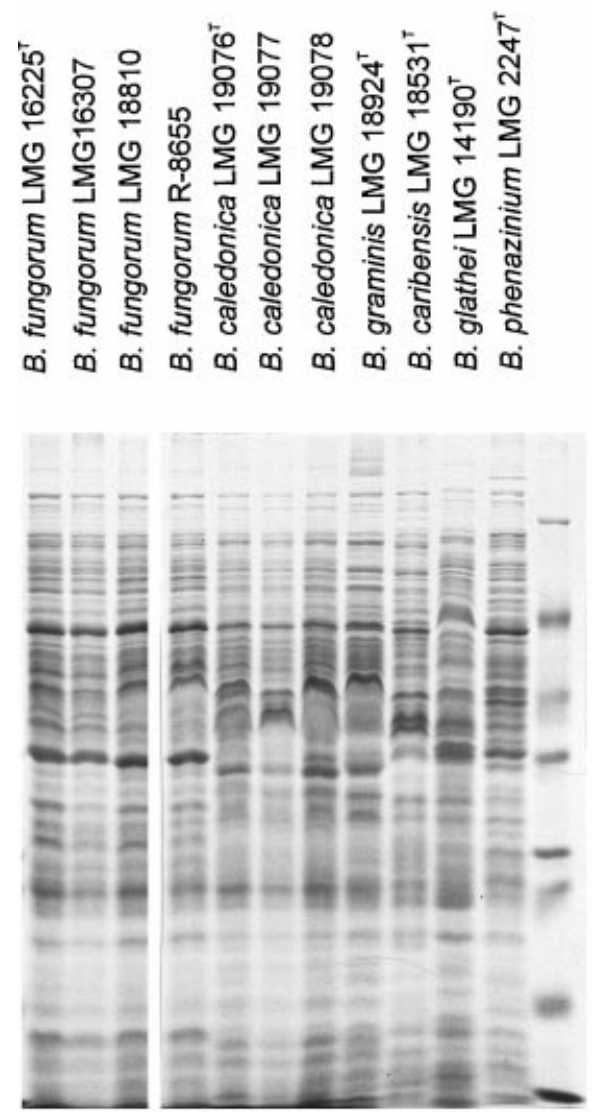

Fig. 2. Electrophoretic protein patterns of a selection of strains investigated. The $M_{r}$ markers used (see right-hand lane) were (from bottom to top) lysozyme (14500), trypsin inhibitor (20000), trypsinogen (24000), glyceraldehyde-3-phosphate dehydrogenase (36000), egg albumin (45000), bovine albumin $(60000)$ and $\beta$-galactosidase (116000).

holderia species occupied distinct positions in the dendrogram. The 16 novel isolates were distributed over three different clusters (clusters I, III and V). Cluster I was composed of an environmental isolate and a human isolate. Cluster III comprised seven strains (two from animals, two from the environment, one human isolate, one nosocomial isolate and one isolate of unknown origin). Cluster VI was composed of seven rhizosphere isolates. A selection of protein patterns of strains from each cluster is shown in Fig. 2.

\section{S rRNA gene sequencing}

The 16S rDNA sequences of strains LMG $16225^{\mathrm{T}}$, LMG 16307 and LMG $19076^{\mathrm{T}}$ were determined and compared with available $16 \mathrm{~S}$ rDNA sequences of other representatives of the $\beta$-Proteobacteria and with each other. The 16S rDNA sequences of strains LMG $16225^{\mathrm{T}}$ and LMG 16307 were identical and were closely related to those of LMG $19076^{\mathrm{T}}(97 \cdot 8 \%$ similarity), B. phenazinium LMG $2247^{\mathrm{T}}$ (98.5\% similarity), B. graminis $\mathrm{LMG} 18924^{\mathrm{T}}$ (97.7\% similarity) and $B$. caribensis LMG $18531^{\mathrm{T}}(96.7 \%$ similarity). The similarity levels of LMG $19076^{\mathrm{T}}$ towards $B$. graminis LMG $18924^{\mathrm{T}}$, B. phenazinium LMG $2247^{\mathrm{T}}$ and $B$. caribensis LMG $18531^{\mathrm{T}}$ were respectively $97 \cdot 7,97 \cdot 0$ and $96.7 \%$ (Fig. 3). Similarity levels towards representatives of other known Burkholderia species were below $95 \cdot 7 \%$. Similarity levels towards other taxa belonging to the $\beta$-Proteobacteria were below $95.4 \%$.

\section{DNA-DNA hybridizations and determination of the $\mathbf{G}+\mathbf{C}$ content}

DNA was prepared from strains representing the three protein-electrophoretic clusters amongst the 16 isolates and from reference strains of $B$. graminis, $B$. caribensis and $B$. phenazinium (their closest phylogenetic neighbours). The DNA-DNA binding values and the $\mathrm{G}+\mathrm{C}$ contents of all strains examined are shown in Table 2. All strains investigated had $\mathrm{G}+\mathrm{C}$ contents between 61.9 and $63.2 \mathrm{~mol} \%$. The hybridization experiments revealed that strains belonging to protein-electrophoretic cluster VI formed one genomic group (a DNA-DNA binding value of $100 \%$ was calculated between two randomly chosen isolates), whereas protein-electrophoretic clusters I and III formed a second genomic group with internal DNADNA binding values of between 85 and $100 \%$. The $B$. graminis and $B$. caribensis reference strains formed a single group, each having internal DNA-DNA binding levels above $95 \%$. The DNA binding values between representatives of the two genomic groups and between representatives of both genomic groups and reference strains of $B$. caribensis and B. phenazinium were below 30 and $28 \%$, respectively. Intermediate DNA-DNA binding levels were calculated between $B$. graminis reference strains and representatives of the two genomic groups $(31-48 \%$ and $32-41 \%$, respectively).

\section{Cellular fatty acid analysis}

The cellular fatty acid composition of all B. graminis, $B$. caribensis and $B$. phenazinium strains and the 16 novel isolates listed in Table 1 was determined. Both quantitative and qualitative differences in cellular fatty acid composition were observed between the strains investigated (Table 3 ). The predominant fatty acids in all strains investigated were 16:0,18:1 $\omega 7 c$, summed feature 2 (comprising 14:0 3-OH, 16:1 iso I, an unidentified fatty acid with an equivalent chain-length value of 10.928 , or 12:0 ALDE, or any combinations of these fatty acids) and summed feature 3 (comprising $16: 1 \omega 7 c$ or 15 iso $2-\mathrm{OH}$ or both).

\section{Phenotypic characterization}

We determined the phenotypic characteristics of all $B$. graminis, B. caribensis and B. phenazinium strains and the 16 novel isolates listed in Table 1 . The results are shown in Table 4. 


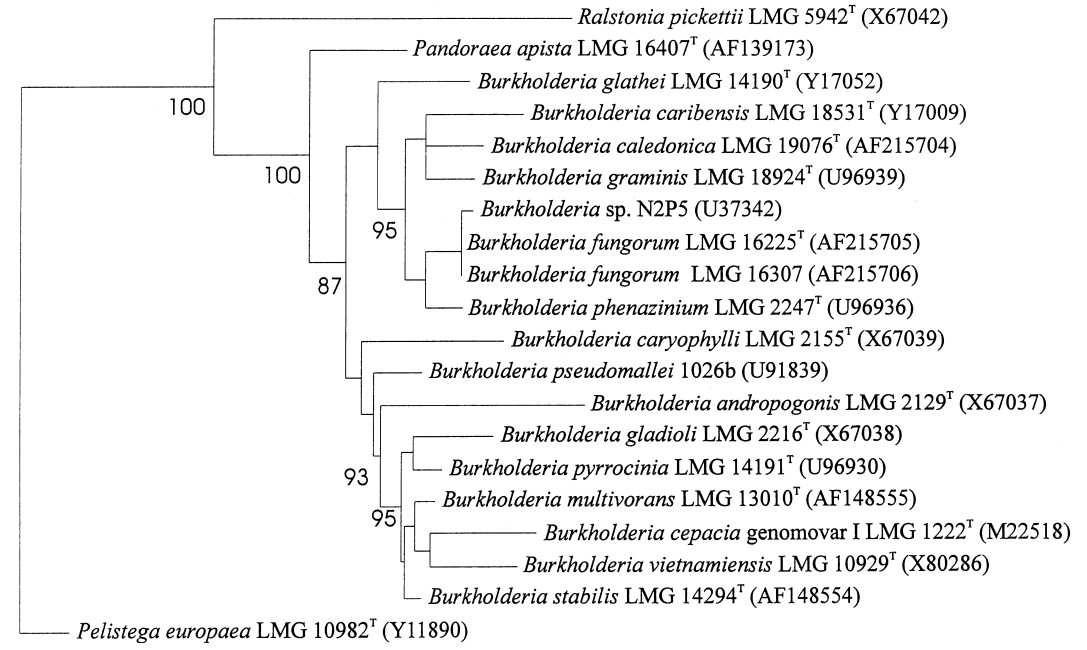

Fig. 3. Neighbour-joining tree showing the phylogenetic position of Burkholderia fungorum and Burkholderia caledonica within the genus Burkholderia, based on 16S rDNA sequence comparisons. Pelistega europaea LMG $10982^{\top}$ (accession no. Y11890) was used as an outgroup in this analysis. Bar, $10 \%$ sequence dissimilarity.

Table 2. DNA-DNA binding values and $G+C$ content of all Burkholderia strains examined

\begin{tabular}{|c|c|c|c|c|c|c|c|c|c|c|c|c|c|}
\hline \multirow[t]{2}{*}{ Strain } & \multirow{2}{*}{$\begin{array}{c}\text { Protein- } \\
\text { electrophoretic } \\
\text { cluster }\end{array}$} & \multirow{2}{*}{$\begin{array}{c}\mathbf{G}+\mathbf{C} \text { content } \\
(\mathbf{m o l} \%)\end{array}$} & \multicolumn{11}{|c|}{ DNA binding (\%) with strain: } \\
\hline & & & 1 & 2 & 3 & 4 & 5 & 6 & 7 & 8 & 9 & 10 & 11 \\
\hline 1. B. graminis LMG $18924^{\mathrm{T}}$ & VII & $62 \cdot 6$ & 100 & & & & & & & & & & \\
\hline 2. B. graminis LMG 18947 & VII & $63 \cdot 2$ & 99 & 100 & & & & & & & & & \\
\hline 3. B. caribensis LMG $18531^{\mathrm{T}}$ & $\mathrm{V}$ & $62 \cdot 8$ & 14 & 16 & 100 & & & & & & & & \\
\hline 4. B. caribensis $\mathrm{LMG} 18532$ & $\mathrm{~V}$ & $62 \cdot 8$ & & & 95 & 100 & & & & & & & \\
\hline 5. B. phenazinium LMG $2247^{\mathrm{T}}$ & II & $62 \cdot 5$ & 29 & 16 & 11 & 13 & 100 & & & & & & \\
\hline 6. B. fungorum LMG $16225^{\mathrm{T}}$ & I & $62 \cdot 2$ & 41 & & 19 & 20 & 26 & 100 & & & & & \\
\hline 7. B. fungorum LMG 18810 & III & $62 \cdot 1$ & 32 & & & & 28 & 97 & 100 & & & & \\
\hline 8. B. fungorum R-9502 & III & $61 \cdot 9$ & & & 14 & & & 85 & & 100 & & & \\
\hline 9. B. fungorum R-8655 & III & ND & & & & & & 90 & & 87 & 100 & & \\
\hline 10. B. caledonica LMG $19076^{\mathrm{T}}$ & VI & $62 \cdot 2$ & 48 & 31 & 16 & & 24 & 27 & 28 & 24 & 26 & 100 & \\
\hline 11. B. caledonica LMG 19077 & VI & $62 \cdot 2$ & 37 & 34 & & & 18 & 30 & & & & 100 & 100 \\
\hline
\end{tabular}

ND, Not determined.

\section{DISCUSSION}

In the present study, we used a polyphasic taxonomic approach, including 16S rDNA sequencing, DNADNA hybridization, extensive biochemical characterization and cellular fatty acid and protein analysis, to determine the relationships and the phylogenetic position of 16 isolates from the environment, animals and human clinical samples.

\section{Characterization of Burkholderia fungorum sp. nov. and Burkholderia caledonica sp. nov.}

It has been reported that SDS-PAGE of whole-cell proteins is a good screening method for the differentiation of Burkholderia species (Vandamme et al., 1997). In the present study, B. graminis, B. phenazinium, B. caribensis and B. glathei reference strains each formed separate clusters, while reference strains of all other Burkholderia species investigated occupied distinct positions in the dendrogram obtained after numerical analysis of the whole-cell protein profiles (Fig. 1). Numerical analysis and visual comparison of the protein profiles of the 16 isolates suggested that at least two different groups were present. To determine the exact degree of genetic relatedness of strains belonging to the different protein-electrophoretic clusters, DNA-DNA hybridizations were performed. The results showed that strains belonging to proteinelectrophoretic cluster VI formed a single species. Strain LMG $16225^{\mathrm{T}}$ (cluster I) exhibited high (85$97 \%$ ) DNA-DNA binding towards strains LMG 18810, R-8655 and R-9502 (cluster III), and therefore these two clusters can be considered as two electrophoretic types of a single species. The protein patterns of strains from the two clusters were very similar, but, 
Table 3. Fatty acid composition of the strains studied

Values are mean percentages of total fatty acids with standard deviations. The numbers of strains tested are shown in parentheses. Summed feature 2 comprises 14:0 3-OH, 16:1 iso I, an unidentified fatty acid with an equivalent chain-length value of 10.928, or 12:0 ALDE, or any combination of these fatty acids. Summed feature 3 comprises $16: 1 \omega 7 c$ or 15 iso $2-\mathrm{OH}$ or both. Fatty acids for which the mean amount in all taxa was less than $1 \%$ are not given. TR, Trace amount $(<1 \%)$.

\begin{tabular}{|c|c|c|c|c|c|}
\hline Fatty acid & B. fungorum (9) & B. caledonica (7) & B. graminis (4) & B. caribensis (2) & B. phenazinium (2) \\
\hline $14: 0$ & $4 \cdot 6 \pm 0 \cdot 1$ & $4 \cdot 7 \pm 0 \cdot 2$ & $4 \cdot 6 \pm 0 \cdot 0$ & $4 \cdot 2 \pm 0 \cdot 0$ & $5 \cdot 1 \pm 0 \cdot 5$ \\
\hline $16: 0$ & $14 \cdot 7 \pm 0 \cdot 9$ & $13 \cdot 6 \pm 1 \cdot 6$ & $14 \cdot 4 \pm 4 \cdot 7$ & $19 \cdot 1 \pm 0 \cdot 6$ & $15 \cdot 7 \pm 2 \cdot 7$ \\
\hline 17:0 cyclo & $5 \cdot 1 \pm 1 \cdot 6$ & $8 \cdot 4 \pm 1 \cdot 5$ & $6 \cdot 9 \pm 1 \cdot 8$ & $10 \cdot 0 \pm 0 \cdot 2$ & $8 \cdot 4 \pm 0 \cdot 5$ \\
\hline $16: 12 \mathrm{OH}$ & $3 \cdot 5 \pm 0 \cdot 7$ & $2 \cdot 7 \pm 0 \cdot 4$ & $5 \cdot 3 \pm 2 \cdot 2$ & $1 \cdot 7 \pm 0 \cdot 1$ & $3 \cdot 0 \pm 1 \cdot 8$ \\
\hline $16: 02-\mathrm{OH}$ & $3 \cdot 6 \pm 0 \cdot 5$ & $2 \cdot 4 \pm 0 \cdot 4$ & $3 \cdot 7 \pm 1 \cdot 6$ & $2 \cdot 2 \pm 0 \cdot 3$ & $2 \cdot 0 \pm 1 \cdot 0$ \\
\hline $16: 03-\mathrm{OH}$ & $5 \cdot 6 \pm 0 \cdot 5$ & $6 \cdot 0 \pm 0 \cdot 4$ & $7 \cdot 0 \pm 0 \cdot 3$ & $4 \cdot 6 \pm 0 \cdot 4$ & $4 \cdot 2 \pm 2 \cdot 0$ \\
\hline $18: 1 \omega 7 c$ & $35 \cdot 6 \pm 2 \cdot 1$ & $34 \cdot 2 \pm 1 \cdot 7$ & $26 \cdot 5 \pm 0 \cdot 9$ & $33 \cdot 8 \pm 0 \cdot 4$ & $30 \cdot 1 \pm 0 \cdot 1$ \\
\hline 19:0 cyclo $\omega 8 c$ & $2 \cdot 5 \pm 0 \cdot 7$ & $3 \cdot 7 \pm 0 \cdot 7$ & $3 \cdot 3 \pm 0 \cdot 9$ & $5 \cdot 3 \pm 0 \cdot 1$ & $6 \cdot 3 \pm 0 \cdot 1$ \\
\hline $18: 12-\mathrm{OH}$ & $1 \cdot 7 \pm 0 \cdot 2$ & $1 \cdot 1 \pm 0 \cdot 3$ & $1 \cdot 8 \pm 0 \cdot 3$ & $\mathrm{TR}$ & $1 \cdot 6 \pm 1 \cdot 0$ \\
\hline Summed feature 2 & $8 \cdot 1 \pm 1 \cdot 1$ & $7 \cdot 4 \pm 0 \cdot 9$ & $9 \cdot 8 \pm 1 \cdot 7$ & $6 \cdot 1 \pm 0 \cdot 6$ & $7 \cdot 3 \pm 0 \cdot 7$ \\
\hline Summed feature 3 & $13 \cdot 6 \pm 1 \cdot 9$ & $14 \cdot 5 \pm 1 \cdot 8$ & $15 \cdot 7 \pm 3 \cdot 0$ & $11 \cdot 2 \pm 0 \cdot 2$ & $12 \cdot 6 \pm 0 \cdot 1$ \\
\hline
\end{tabular}

because of distortions of the protein patterns of strains of cluster III, the strains grouped into different clusters. $16 \mathrm{~S}$ rDNA sequence analysis of representative strains of the two genomic groups (LMG 16225 ${ }^{\mathrm{T}}$, LMG 16307 and LMG $19076^{\mathrm{T}}$ ) showed that they formed a stable phylogenetic clade together with $B$. graminis, $B$. phenazinium and $B$. caribensis (internal similarity levels were greater than $96.0 \%$ and the bootstrap value was $95 \%$ ). Other closely related species included $B$. glathei and $B$. caryophylli, but similarities to these species were below $95.7 \%$. Similarity levels of members of the $B$. graminis clade towards the type species (B. cepacia) were between 92.4 and $93.8 \%$. These data indicated unambiguously that protein-electrophoretic clusters I and III and cluster VI represent two novel species within the genus Burkholderia, for which we propose the names $B$. fungorum sp. nov. and B. caledonica $\mathrm{sp}$. nov.

\section{Identification of $B$. fungorum and $B$. caledonica}

Figs 1 and 2 illustrate the fact that B. fungorum and $B$. caledonica are characterized by different whole-cell protein profiles. However, the presence of distortions in the patterns, similar to the distortions reported for other Burkholderia and Ralstonia strains (Vandamme et al., 1997, 1999; Coenye et al., 1999b), hinders the identification of strains solely on the basis of numerical analysis. Therefore, visual comparison of the protein profiles is essential to avoid misidentification. Both quantitative and qualitative differences occur in the fatty acid compositions of the different species investigated (Table 3 ). In particular, the relatively small amount of $18: 1 \omega 7 c$ in $B$. graminis allows it to be differentiated from $B$. fungorum and B. caledonica. The absence of significant amounts of 18:1 2-OH in $B$. caribensis separates it from B. graminis, B. fungorum and $B$. caledonica. In general, however, the differences in fatty acid composition are small, and it is ques- tionable whether they are sufficient to enable identification of strains to the species level. Differential biochemical tests are summarized in Table 4 . The most important tests for differentiating B. fungorum, $B$. caledonica, B. graminis, B. caribensis and B. phenazinium are as follows: the assimilation of trehalose, citrate, DL-norleucine, adipate and sucrose; nitrate reduction; growth in the presence of $0.5 \% \mathrm{NaCl}$; and $\beta$-galactosidase activity.

\section{Taxonomic position of Burkholderia sp. strains EN-B9, EN-B3, N2P6, N2P5, N3P2, Dha-54, VUN10013 and LB400}

During comparison of the 16S rDNA sequences of representatives of B. fungorum and B. caledonica with available $16 \mathrm{~S}$ rRNA sequences of other representatives of the $\beta$-Proteobacteria, relatively high similarities were noted towards Burkholderia sp. strains EN-B9 (GenBank accession no. AF074712), EN-B3 (AF074711), N2P6 (U37343), N2P5 (U37342), N3P2 (U37344), Dha-54 (AJ011508), VUN10013 (AF068011) and LB400 (U86373). All of these strains were isolated during studies on the biodegradation of xenobiotics. Strain N2P5 was isolated from a polycyclic-aromatic-hydrocarbon-contaminated soil enriched with phenanthrene (Mueller et al., 1997) and shows more than $99 \cdot 5 \% 16 \mathrm{~S}$ rDNA sequence similarity to B. fungorum strains (Fig. 3). This strongly suggests that strain N2P5 belongs to B. fungorum. A polyphasic taxonomic study, including DNA-DNA hybridizations, will be required to clarify the exact relationships between these strains and $B$. graminis, $B$. caribensis, $B$. phenazinium, $B$. fungorum and $B$. caledonica. The close phylogenetic relationships between these strains and $B$. graminis, B. caribensis, B. phenazinium, B. fungorum and $B$. caledonica suggest that other strains of the $B$. graminis clade might have similar useful xenobioticcompound-degrading properties. 
Table 4. Phenotypic characteristics of $B$. fungorum and $B$. caledonica and related species

The numbers of strains tested are shown in parentheses. Characteristics are scored as: + , all strains tested gave a positive reaction; - , none of the strains tested gave a positive reaction; $\mathrm{v}(+)$, result is strain dependent and the type strain is positive; $\mathrm{V}$ $(-)$, result is strain dependent and the type strain is negative. The following features are present in all strains investigated: growth at $30{ }^{\circ} \mathrm{C}$; hydrolysis of Tween 80 ; assimilation of D-glucose, D-mannose, D-mannitol, D-gluconate, phenylacetate, L-malate and DL-lactate; alkaline and acid phosphatase, $\mathrm{C}_{8}$-ester lipase, leucine arylamidase and phosphoamidase activity. The following features are absent in all strains investigated: haemolysis; growth at $42{ }^{\circ} \mathrm{C}$; production of fluorescent pigment; growth in the presence of $3.0,4.5$ or $6.0 \% \mathrm{NaCl}$ or acetamide; denitrification; nitrite reduction; aesculin hydrolysis; production of indole; production of acid or $\mathrm{H}_{2} \mathrm{~S}$ in triple-sugar-iron agar; assimilation of maltose; ornithine and lysine decarboxylase, tryptophanase, arginine dihydrolase, urease, gelatinase, DNase, trypsin, chymotrypsin, $\alpha$-galactosidase, $\beta$-glucuronidase, $\alpha$-glucosidase, $N$-acetyl$\beta$-glucosidase, $\alpha$-mannosidase and $\alpha$-fucosidase activity.

\begin{tabular}{|c|c|c|c|c|c|}
\hline Characteristic & B. caledonica (7) & B. fungorum (9) & B. graminis (4) & B. caribensis (2) & B. phenazinium (2) \\
\hline Catalase activity & + & $\mathrm{v}(+)$ & + & + & - \\
\hline Oxidase activity & - & $\mathrm{v}(+)$ & $\mathrm{V}(-)$ & - & $\mathrm{v}(+)$ \\
\hline Growth at $37^{\circ} \mathrm{C}$ & $\mathrm{v}(-)$ & + & + & + & $\mathrm{v}(+)$ \\
\hline \multicolumn{6}{|c|}{ Growth in OF medium with: } \\
\hline D-Glucose & + & + & $\mathrm{v}(+)$ & + & $\mathrm{v}(-)$ \\
\hline Maltose & $\mathrm{v}(+)$ & $\mathrm{V}(-)$ & - & - & $\mathrm{v}(-)$ \\
\hline Adonitol & $\mathrm{v}(+)$ & $\mathrm{V}(-)$ & $\mathrm{v}(+)$ & $\mathrm{v}(+)$ & - \\
\hline D-Fructose & + & $\mathrm{v}(+)$ & + & $\mathrm{v}(+)$ & + \\
\hline D-Xylose & + & $\mathrm{v}(+)$ & $\mathrm{v}(+)$ & - & $\mathrm{v}(-)$ \\
\hline Growth on cetrimide & - & $\mathrm{v}(+)$ & - & - & - \\
\hline Nitrate reduction & - & + & + & - & - \\
\hline \multicolumn{6}{|l|}{ Growth in the presence of: } \\
\hline $0.5 \% \mathrm{NaCl}$ & $\mathrm{v}(+)$ & + & $\mathrm{v}(+)$ & - & - \\
\hline $1.5 \% \mathrm{NaCl}$ & $\mathrm{v}(-)$ & $\mathrm{v}(+)$ & $\mathrm{v}(+)$ & - & - \\
\hline $10 \%$ Lactose & $\mathrm{v}(+)$ & - & - & - & - \\
\hline \multicolumn{6}{|l|}{ Assimilation of: } \\
\hline Trehalose & + & - & + & - & - \\
\hline L-Arginine & + & $\mathrm{v}(+)$ & + & + & + \\
\hline DL-Norleucine & - & $\mathrm{v}(+)$ & - & + & - \\
\hline L-Arabinose & + & $\mathrm{v}(+)$ & + & + & $\mathrm{v}(+)$ \\
\hline$N$-Acetylglucosamine & $\mathrm{v}(+)$ & + & + & + & + \\
\hline Caprate & $\mathrm{v}(-)$ & $\mathrm{v}(+)$ & + & + & - \\
\hline Adipate & $\mathrm{v}(-)$ & $\mathrm{v}(+)$ & + & - & - \\
\hline Citrate & - & + & + & + & - \\
\hline Sucrose & $\mathrm{v}(-)$ & - & + & - & + \\
\hline \multicolumn{6}{|l|}{ Activity of: } \\
\hline$\beta$-Galactosidase & - & - & - & + & - \\
\hline $\mathrm{C}_{4}$-Esterase & $\mathrm{v}(-)$ & $\mathrm{v}(+)$ & $\mathrm{v}(+)$ & $\mathrm{V}(-)$ & + \\
\hline $\mathrm{C}_{14}$-Lipase & - & $\mathrm{v}(-)$ & - & - & - \\
\hline Valine arylamidase & - & - & - & $\mathrm{v}(+)$ & $\mathrm{v}(-)$ \\
\hline Cysteine arylamidase & $\mathrm{v}(-)$ & $\mathrm{v}(+)$ & $\mathrm{v}(+)$ & $\mathrm{v}(+)$ & - \\
\hline$\beta$-Glucosidase & - & - & - & $\mathrm{v}(+)$ & - \\
\hline
\end{tabular}

\section{Description of Burkholderia fungorum sp. nov.}

Burkholderia fungorum (fun.go'rum. L. n. fungus mushroom; L. gen. pl. n. fungorum of fungi).

Cells are Gram-negative, non-sporulating, straight rods. Growth is observed at $30^{\circ} \mathrm{C}$ and in the presence of $0.5 \% \mathrm{NaCl}$, but not at $42{ }^{\circ} \mathrm{C}$. Nitrite is not reduced. Nitrate is reduced. No DNase activity, $\beta$-galactosidase activity, urease activity, liquefaction of gelatin, aesculin hydrolysis or indole production. Assimilation of citrate but not of trehalose or sucrose. Additional characteristics are listed in Table 4 . The following fatty acids are present in all strains: $14: 0,16: 0,17: 0$ cyclo, 16:1 2-OH, 16:0 2-OH, 16:0 3-OH, 18:1 $\omega 7 c, 19: 0$ cyclo $\omega 8 c$, summed feature 2 (comprising 14:0 3-OH, 16: 1 iso $\mathrm{I}$, an unidentified fatty acid with an equivalent chain-length value of 10.928, or 12:0 ALDE, or any combinations of these fatty acids) and summed feature 3 (comprising $16: 1 \omega 7 c$ or 15 iso $2-\mathrm{OH}$ or both). The $\mathrm{G}+\mathrm{C}$ content is $61 \cdot 9-62 \cdot 2 \mathrm{~mol} \%$. B. fungorum strains have been isolated from fungi, animals and human clinical samples. Several isolates of this species have been isolated from the white-rot fungus Phanerochaete chrysosporium. These bacteria appeared to be very 
closely associated with the fungus, and attempts to eliminate the bacteria were unsuccessful (SeigleMurandi et al., 1996). It has been suggested that there is a symbiotic relationship between the bacteria and the fungus, since the bacteria were very efficient degraders of the aromatic compounds derived from degradation of lignin by white-rot fungi (SeigleMurandi et al., 1996). Recently, several unidentified $B$. cepacia-like strains isolated from cystic fibrosis patients were also classified as $B$. fungorum (our unpublished observations).

The type strain, LMG $16225^{\mathrm{T}}$ ( = CCUG $31961^{\mathrm{T}}$ ), was isolated from the white-rot fungus $P$. chrysosporium. The type strain has the following additional characteristics: growth in $\mathrm{O} / \mathrm{F}$ medium with fructose and xylose, on cetrimide and in the presence of $1.5 \%$ $\mathrm{NaCl}$; assimilation of L-arginine, DL-norleucine, Larabinose, caprate and adipate; $\mathrm{C}_{4}$-esterase and cysteine arylamidase activity; $\mathrm{G}+\mathrm{C}$ content of 62 $\mathrm{mol} \%$.

\section{Description of Burkholderia caledonica sp. nov.}

Burkholderia caledonica (ca.le.do'nica. L. n. Caledonia Latin name for the Scottish Highlands; L. adj. caledonica of Scotland, from where the strains were isolated).

Cells are Gram-negative, non-sporulating, straight rods. Catalase activity is present. Growth is observed at $30{ }^{\circ} \mathrm{C}$, but not at $42{ }^{\circ} \mathrm{C}$. Nitrate and nitrite are not reduced. No DNase activity, $\beta$-galactosidase activity, liquefaction of gelatin, aesculin hydrolysis or indole production. Assimilation of trehalose but not citrate. Additional characteristics are listed in Table 4. The following fatty acids are present in all strains: 14:0, 16:0, 17:0 cyclo, 16:1 2-OH, 16:0 2-OH, 16:0 3-OH, 18:1 $\omega 7 c, 19: 0$ cyclo $\omega 8 c$, summed feature 2 (comprising 14:0 3-OH, 16:1 iso I, an unidentified fatty acid with an equivalent chain-length value of 10.928 , or 12:0 ALDE, or any combinations of these fatty acids) and summed feature 3 (comprising $16: 1 \omega 7 c$ or 15 iso $2-\mathrm{OH}$ or both). B. caledonica strains have been isolated from the rhizosphere.

The type strain, LMG $19076^{\mathrm{T}}$ ( = CCUG $42236^{\mathrm{T}}$ ), was isolated from the rhizosphere. The type strain has the following additional characteristics: growth in $\mathrm{O} / \mathrm{F}$ medium with adonitol and maltose and in the presence of $10 \%$ lactose and $0.5 \% \mathrm{NaCl}$; assimilation of $\mathrm{N}$ acetylglucosamine; no assimilation of caprate, adipate or sucrose; no $\mathrm{C}_{4}$-esterase or cysteine arylamidase activity; $\mathrm{G}+\mathrm{C}$ content of $62 \mathrm{~mol} \%$.

\section{ACKNOWLEDGEMENTS}

T.C. acknowledges the support received from the Vlaams Instituut voor Bevordering van Wetenschappelijk-technologisch onderzoek in de Industrie (Belgium) in the form of a bursary for advanced study. P.V., A.W. and M.G. are indebted to the Fund for Scientific Research-Flanders (Belgium) for a position as a postdoctoral fellow and for research and personnel grants, respectively. We acknowledge the financial support received from the Cystic Fibrosis Trust (UK) (grant RS15). We wish to thank Dirk Dewettinck, Tim Goossens, Liesbeth Lebbe and Urbain Torck for excellent technical assistance.

\section{REFERENCES}

Achouak, W., Christen, R., Barakat, M., Martel, M.-H. \& Heulin, T. (1999). Burkholderia caribensis sp. nov., an exopolysaccharideproducing bacterium isolated from vertisol microaggregates in Martinique. Int J Syst Bacteriol 49, 787-794.

Brett, P. J., DeShazer, D. \& Woods, D. E. (1998). Burkholderia thailandensis sp. nov., a Burkholderia pseudomallei-like species. Int J Syst Bacteriol 48, 317-320.

Butler, S. L., Doherty, C. J., Hughes, J. E., Nelson, J. W. \& Govan, J. R. W. (1995). Burkholderia cepacia and cystic fibrosis: do natural environments present a potential hazard? $J$ Clin Microbiol 33, 1001-1004.

Coenye, T., Holmes, B., Kersters, K., Govan, J. R. W. \& Vandamme, P. (1999a). Burkholderia cocovenenans (van Damme et al. 1960) Gillis et al. 1995 and Burkholderia vandii Urakami et al. 1994 are junior synonyms of Burkholderia gladioli (Severini 1913) Yabuuchi et al. 1993 and Burkholderia plantarii (Azegami et al. 1987) Urakami et al. 1994, respectively. Int J Syst Bacteriol 49, $37-42$.

Coenye, T., Falsen, E., Vancanneyt, M., Hoste, B., Govan, J. R. W., Kersters, K. \& Vandamme, P. (1999b). Classification of Alcaligenes faecalis-like isolates from the environment and human clinical samples as Ralstonia gilardii sp. nov. Int J Syst Bacteriol 49, 405-413.

Coenye, T., LiPuma, J. J., Henry, D., Hoste, B., Vandemeulebroecke, K., Gillis, M., Speert, D. P. \& Vandamme, P. (2001). Burkholderia cepacia genomovar VI, a new member of the Burkholderia cepacia complex isolated from cystic fibrosis patients. Int J Syst Evol Microbiol 51, 271-279.

Ezaki, T., Hashimoto, Y. \& Yabuuchi, E. (1989). Fluorometric deoxyribonucleic acid-deoxyribonucleic acid hybridization in microdilution wells as an alternative to membrane filter hybridization in which radioisotopes are used to determine genetic relatedness among bacterial strains. Int J Syst Bacteriol 39, 224-229.

Gillis, M., Van Van, T., Bardin, R. \& 7 other authors (1995). Polyphasic taxonomy in the genus Burkholderia leading to an emended description of the genus and proposition of Burkholderia vietnamiensis sp. nov. for $\mathrm{N}_{2}$-fixing isolates from rice in Vietnam. Int J Syst Bacteriol 45, 274-289.

Mesbah, M., Premachandran, U. \& Whitman, W. B. (1989). Precise measurement of the $\mathrm{G}+\mathrm{C}$ content of deoxyribonucleic acid by high-performance liquid chromatography. Int J Syst Bacteriol 39, 159-167.

Mueller, J. G., Devereux, R., Santavy, D. L., Lantz, S. E., Willis, S. G. \& Pritchard, P. H. (1997). Phylogenetic and physiological comparisons of PAH-degrading bacteria from geographically diverse soils. Antonie Leeuwenhoek 71, 329-343.

Pitcher, D. G., Saunders, N. A. \& Owen, R. J. (1989). Rapid extraction of bacterial genomic DNA with guanidium thiocyanate. Lett Appl Microbiol 8, 109-114.

Pot, B., Vandamme, P. \& Kersters, K. (1994). Analysis of electrophoretic whole-organism protein fingerprints. In Chemical Methods in Prokaryotic Systematics, pp. 493-521. Edited by M. Goodfellow \& A. G. O’Donnell. Chichester: Wiley.

Seigle-Murandi, F., Guiraud, P., Croizé, J., Falsen, E. \& Eriksson, 
K.-E. L. (1996). Bacteria are omnipresent on Phanerochaete chrysosporium Burdsall. Appl Environ Microbiol 62, 2477-2481.

Vandamme, P., Vancanneyt, M., Pot, B. \& 10 other authors (1992). Polyphasic taxonomic study of the emended genus Arcobacter with Arcobacter butzleri comb. nov. and Arcobacter skirrowii sp. nov., an aerotolerant bacterium isolated from veterinary specimens. Int $J$ Syst Bacteriol 42, 344-356.

Vandamme, P., Gillis, M., Vancanneyt, M., Hoste, B., Kersters, K. \& Falsen, E. (1993). Moraxella lincolnii sp. nov., isolated from the human respiratory tract, and re-evaluation of the taxonomic position of Moraxella osloensis. Int J Syst Bacteriol 43, 474- 481.

Vandamme, P., Holmes, B., Vancanneyt, M. \& 8 other authors (1997). Occurrence of multiple genomovars of Burkholderia cepacia in cystic fibrosis patients and proposal of Burkholderia multivorans sp. nov. Int J Syst Bacteriol 47, 1188-1200.

Vandamme, P., Goris, J., Coenye, T., Hoste, B., Janssens, D., Kersters, K., De Vos, P. \& Falsen, E. (1999). Assignment of Centers for Disease Control group IVc-2 to the genus Ralstonia as Ralstonia paucula sp. nov. Int J Syst Bacteriol 49, 663-669.

Vandamme, P., Mahenthiralingam, E., Holmes, B., Coenye, T., Hoste, B., De Vos, P., Henry, D. \& Speert, D. P. (2000). Identification and population structure of Burkholderia stabilis sp. nov. (formerly Burkholderia cepacia genomovar IV). J Clin Microbiol 38, 1042-1047.

Viallard, V., Poirier, I., Cournoyer, B., Haurat, J., Wiebkin, S., Ophel-Keller, K. \& Balandreau, J. (1998). Burkholderia graminis sp. nov., a rhizospheric Burkholderia species, and reassessment of [Pseudomonas] phenazinium, [Pseudomonas] pyrrocinia and [Pseudomonas] glathei as Burkholderia. Int J Syst Bacteriol 48, 549-563.

Yabuuchi, E., Kosako, Y., Oyaizu, H., Yano, I., Hotta, H., Hashimoto, Y., Ezaki, T. \& Arakawa, M. (1992). Proposal of Burkholderia gen. nov. and transfer of seven species of the genus Pseudomonas homology group II to the new genus, with the type species Burkholderia cepacia (Palleroni and Holmes 1981) comb. nov. Microbiol Immunol 36, 1251-1275.

Yabuuchi, E., Kosako, Y., Yano, I., Hotta, H. \& Nishiuchi, Y. (1995). Transfer of two Burkholderia and an Alcaligenes species to Ralstonia gen. nov.: proposal of Ralstonia pickettii (Ralston, Palleroni and Doudoroff 1973) comb. nov., Ralstonia solanacearum (Smith 1896) comb. nov. and Ralstonia eutropha (Davis 1969) comb. nov. Microbiol Immunol 39, 897-904.

Yabuuchi, E., Kawamura, Y., Ezaki, T., Ikedo, M., Dejsirilert, S., Fujiwara, N., Naka, T. \& Kobayashi, K. (2000). Burkholderia uboniae sp. nov., L-arabinose-assimilating but different from Burkholderia thailandensis and Burkholderia vietnamiensis. Microbiol Immunol 44, 307-317.

Zhang, H., Hanada, S., Shigematsu, T., Shibuya, K., Kamagata, Y., Kanagawa, T. \& Kurane, R. (2000). Burkholderia kururiensis sp. nov., a trichloroethylene (TCE)-degrading bacterium isolated from an aquifer polluted with TCE. Int J Syst Evol Microbiol 50, 743-749. 